\title{
Methodology for Formation of the Cost of the Innovation Project
}

\author{
Maxim O. Iskoskov ${ }^{1} \&$ Ljiljana A. Sosunova ${ }^{2}$ \\ ${ }^{1}$ Togliatti State University, Togliatti, Russian Federation \\ ${ }^{2}$ Samara State University of Economics, Russian Federation \\ Correspondence: Ljiljana A. Sosunova, Soviet Army str., 141, Samara, 443090, Russian Federation. E-mail: \\ maksim250881@mail.ru
}

Received: October 14, 2014 Accepted: December 26, 2014 Online Published: March 20, 2015

doi:10.5539/ass.v11n8p162 URL: http://dx.doi.org/10.5539/ass.v11n8p162

\begin{abstract}
The authors of the present study propose the methodology for formation of the cost of the innovation project based on the application of the process approach. The essence of this methodology is to represent each stage of the innovation project as a scheme of interrelated business processes, decomposition of which occurs up to the level of functions and even at this level takes place a valuation of each of these functions, which allows to most effectively consider all types of costs at the formation of the project budget.
\end{abstract}

Keywords: innovation, innovation project, project cost, project management, intangible assets, cost management

\section{Introduction}

Nowadays one of the competitive advantages of any enterprise, regardless of its ownership form, the types of products sold, services rendered or enterprise-wide, is the realization of innovation activity, while the innovation projects serve as one of the ways of its implementation. The development and implementation of the innovation project require attraction of investments - both internal (through budget planning, at the expense of the company's profit or mobilization of internal resources) and external investments (by attracting investors, with the help of state support) (Atoyan, 2009, pp. 3-8; Korolev, 2010, pp. 63-67; Laskowski, 2009; Hill, 2009; Wheelen, 2011; Wheelen, 2009).

One of the criteria of the innovation project attractiveness is its cost, i.e. total costs involved in its development and implementation (Laskowski, 2007, pp. 19-31; Tukkel, 2011).

The correct determination of the cost of the innovation project has great significance for the results of the project. The evaluation of the project efficiency, planning of the effective use of investments and mobilization of internal resources depend on the way how accurately the cost, presented as a cost estimate, reflects the level of necessary expenses. The accuracy of the estimates shall be determined by a complex of works, literacy and optimality of assumptions (Christensen, 2008; Cool, 2002, pp. 55-71; Dodgson, 2009; Brunner, 2011).

On the basis of the indicated cost of the innovation project determined the amount of capital investment, which includes design costs, purchase costs of the equipment necessary for the project, the cost of control over activities on the development of project documentation, and other costs (Novikov, 2007; Dyer, 2011).

The determination of the design costs is also necessary for establishing the contracted price at the conclusion of contracts between innovation stakeholders, as well as for the stakeholders' settlement in the case when some of the life cycle stages of the innovation project are conducted by attracting partners and outsourcers (Kandrashina, 2009, pp. 50-54; Norn, 2008).

The basis for budgeting preparations of the innovation project is a schedule and cost estimate, after that the implementation of accounting and evaluation of the project participants can take place. In this regard, the project cost determined by the estimate shall ensure covering of expenses and receiving of certain profit. The analysis of the difference between the design costs indicated in the estimate and actual costs shall be the basis for determining the sources of profits and losses. But the estimate is always of the project nature, and the final cost of the project shall be determined on the basis of the end of funding.

It is necessary to plan the costs so that they meet the needs of the project in part of financing for the entire duration of its implementation, which conditions the feasibility of the development of the project budget, presented in the form of the plan and expressed in quantitative indicators, it also reflects the expenditure required 
to achieve the goals (Karpov, 2003; Karpov, 2000).

\section{Methods}

\subsection{Cost Planning at Innovation Development}

Cost planning in the preparation of the budget plan of the innovation project is proposed to be conducted by general-to-specific way, i.e. from the particular life cycle stage of the innovation project to each stage, while the allocation of financial resources for the implementation of the innovation project is carried out periodically at three levels.

At the first level occurs the summation of all functions, reflected in the project schedule. In this case, conducted the analysis of planning alternatives of expenditure level at early stages of work performance, at later stages and at the average level, which is most probable.

At the second level the cost value is determined by summing the cost of works in accordance with the time periods indicated in the project schedule.

The third level is aimed at the distribution of costs for each activity in accordance with the time given in the schedule. Therewith it is useful to consider the various options for the use of funds: fast, medium and slow options.

The control system for the budget flow shall allow timely making amendments to the budget, as well as giving the opportunity to conduct and adjust it with account for changes in the conditions of the project implementation. The effectiveness of the innovation project implementation is provided by a comparison of planned and actual values.

Table 1. Evaluation of the effectiveness of the project implementation

\begin{tabular}{|c|c|c|c|}
\hline Project stage & Evaluation type & Evaluation purposes & Evaluation error, \% \\
\hline $\begin{array}{l}\text { Development of the } \\
\text { project concept }\end{array}$ & $\begin{array}{l}\text { Preliminary } \\
\text { evaluation }\end{array}$ & $\begin{array}{l}\text { Evaluation of the financial } \\
\text { implementation of the project }\end{array}$ & $25-40$ \\
\hline $\begin{array}{l}\text { Development } \\
\text { feasibility study }\end{array}$ & Financial estimates & The final investment decision & $10-20$ \\
\hline $\begin{array}{l}\text { Development of detailed } \\
\text { project documentation }\end{array}$ & $\begin{array}{l}\text { Final estimate } \\
\text { documentation }\end{array}$ & $\begin{array}{l}\text { Basis for the project cost } \\
\text { management }\end{array}$ & $3-5$ \\
\hline \multirow{2}{*}{ Project commissioning } & Actual evaluation & & - \\
\hline & Predictive evaluation & & $3-5$ \\
\hline Project completion & Actual evaluation & $\begin{array}{l}\text { Overall evaluation of the project } \\
\text { cost }\end{array}$ & 0 \\
\hline
\end{tabular}

Depending on the life cycle stage of the innovation project and evaluation purposes, different types and methods of evaluation of the project cost are used. Based on the evaluation purposes the accuracy of such estimates can also be different.

The composition of the costs included in the cost value of the research and development (R\&D) object in accordance with Russian and international standards, is presented in Table 2.

As can be seen from the table below, the list of expenses included in the cost value of the R\&D object (internally generated intangible asset), in accordance with national and international standards, generally differs. They include the following costs: material, labor, and other costs directly related to the process under consideration, depreciation allocations. In addition, in accordance with international standards the costs of training staff to work with the asset, administrative and commercial expenses charged to profit reduction for the reporting period, are not included in the cost of the internally generated intangible asset. Under Russian law, administrative (general) costs may be included in the value of the assets, if they are directly connected with their creation.

The costs of the innovation project (internally generated intangible asset) listed in Table 1, in accordance with Russian and international standards, depending on the stage of their occurrence and the results obtained, shall be subject either to the charge-off on expenses of the reporting period or capitalization. Thus, in accordance with international standards on the stage of the research implementation, the company cannot be sure of getting a certain income, therefore the research costs shall be recognized as expenses incurred in the period of their formation, the profit for the reporting period shall be decreased. Therefore, these costs shall not be capitalized or form the cost of the intangible asset. 
Table 2. The composition of the costs included in the cost value of the R\&D object of the innovation project (internally generated intangible asset)

Russian standards
The cost of inventories and services of third-party
organizations and individuals to be used when performing
these works
Costs for salaries and other payments to employees
directly involved in carrying out the specified works under
the employment contract
Social contributions
The cost of special equipment and special tooling to be
used as objects of tests and studies

Depreciation of fixed and intangible assets used in carrying out the specified works

The cost of maintenance and operation of research facilities, installations, structures, and other objects

The cost of fixed assets and other property

General running costs in case if they are directly linked to the implementation of these activities

Other costs associated with R\&D implementation, taking into account the costs of the tests

\section{International standards}

Costs of materials and services used or consumed in creating intangible assets

Costs of employee benefits, in connection with the creation of intangible assets

Amortization of patents and licenses used to create intangible assets

Trade, administration and other general overhead costs, as well as the costs of training personnel to work with the asset

The fee for registration of legal rights

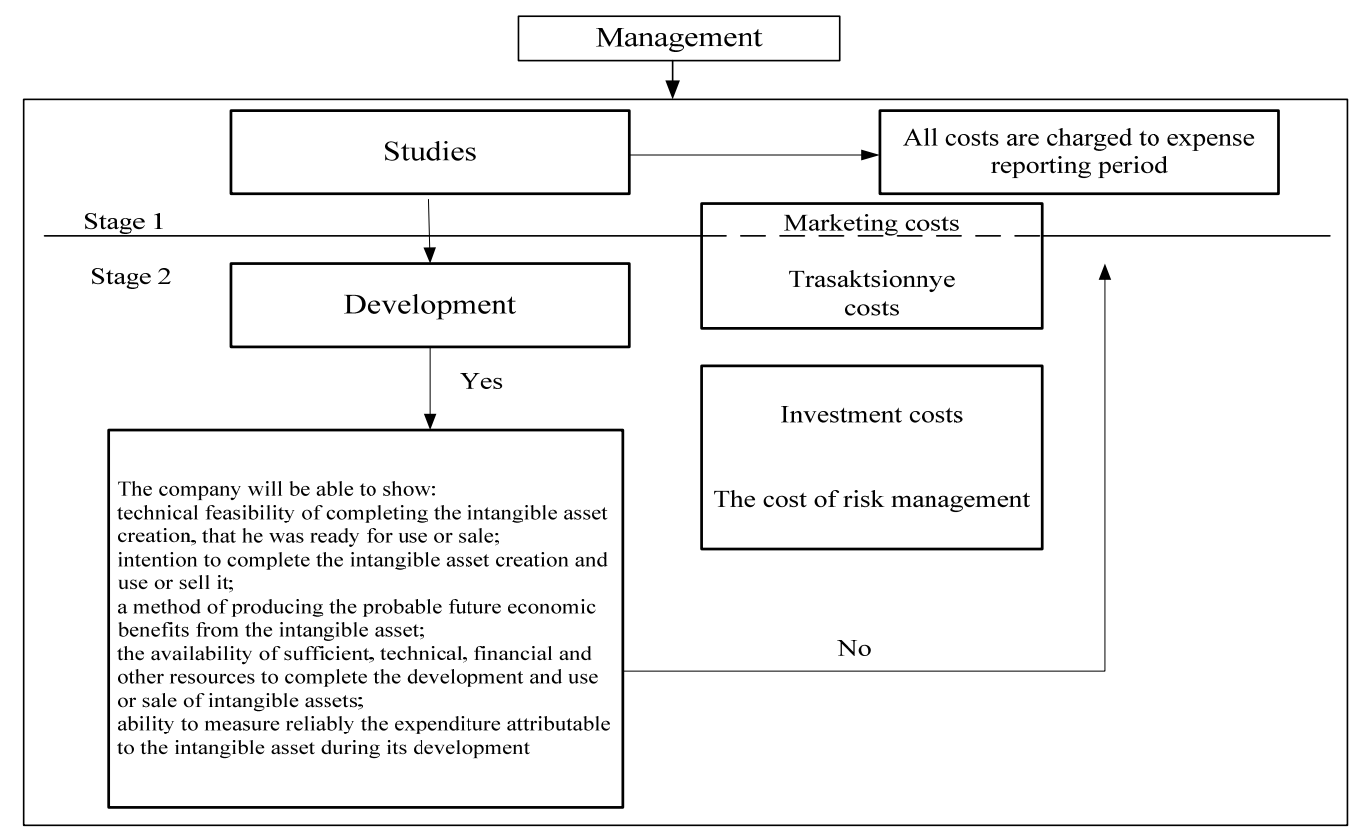

Figure 1. The essence of the costs of the internal creation of intangible assets in accordance with international standards

The costs incurred at the stage of development, in accordance with international standards, can only be capitalized only at the simultaneous satisfaction of several conditions, among which we can set aside the following:

- The creation of the intangible asset is technically feasible, the company has the resources necessary to complete the stage of the asset development; 
- The organization intends to use the asset created in its activity, or sell it;

- The asset shall generate future economic benefits (if there is a relevant market or in case when the utility of the asset for the organization is substantiated);

- The costs related to the intangible assets during its development can be reliably measured.

At failure to meet these conditions, these costs shall be recognized as the expenses of the reporting period are similar to the costs incurred in the research stage (Figure 1).

If the organization cannot make a distinction between the stage of research and development in the framework of the project with the purpose of creation of intangible assets, it can consider the costs of this project as the costs incurred only in connection with the implementation of the research stage.

\subsection{The Essence of the Costs of the Internal Creation of Intangible Assets}

The difference between the internal and international standards is that they do not give an answer to the question what to do with the costs incurred as a result of R\&D activity, up to completion stage of the works. Upon receipt of a positive result on the basis of R\&D the costs shall be recognized as a part of the asset composition. In the absence of a positive result the costs are charged off on other costs of the reporting period. Moreover, Russian rules stipulate that one of the conditions for capitalization of $R \& D$ costs shall be the fact of documentary evidence of works implementation (for example, delivery and acceptance act), whereas in the international standards the similar recognition criterion is absent. The order of reflection of R\&D costs in the financial statements in accordance with the standards of the Russian Federation is shown in Figure 2.

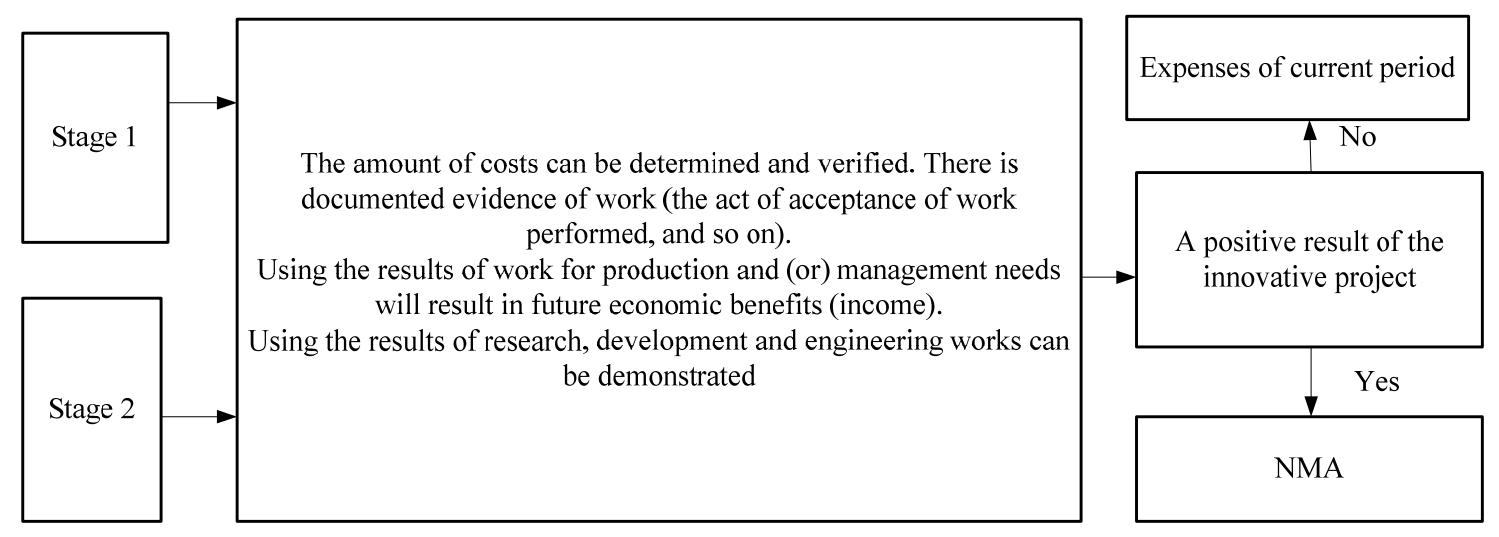

Figure 2. The costs of the innovation project in accordance with Russian standards

According to the international standards, the subsequent evaluation of all intangible assets, including internally generated ones, can be carried out using one of two methods:

1) Evaluation at the primary cost less accumulated depreciation and any accumulated impairment losses;

2) Evaluation at the revalued amount, being the fair value of the asset at the date of revaluation, less subsequent accumulated depreciation and impairment losses. Thus the fair value is considered as the amount that can be gained from the sale of the asset in the result of the transaction between independent, knowledgeable parties willing to conclude a deal. The evaluation of the fair value is carried out according to the active market data at the time of revaluation. Due to the individual nature of the internally generated intangible assets the opportunities for carrying out their revaluation with the requirement on the active market, according to the author, are limited.

Russian law provisions do not provide the revaluation of the R\&D object. The costs of R\&D works can be reflected in the amount of initially recognized costs less the costs written off on the reporting date in accordance with established costs procedure.

The generalization of the order of the subsequent evaluation of capitalized R\&D costs (internally generated intangible assets) under Russian and international standards are presented in Table 3.

Research of the automobile complex activities showed that the costs of innovation project are recognized as the costs related to the creation of new products or the improvement of products (goods, works, services), the creation of new technologies or the improvement of the technologies used, production and management methods, 
grouped in tax accounting of the taxpayer in accordance with the classification provided in Clause 2 of Article 262 of the Tax Code of the Russian Federation (www.nanonewsnet.ru).

Table 3. The subsequent evaluation of the R\&D object (internally generated intangible assets)

\begin{tabular}{|c|c|}
\hline Russian standards & International standards \\
\hline \multirow{3}{*}{$\begin{array}{l}\text { R\&D costs are reflected in the amount of initially recognized } \\
\text { costs less the costs written off on the reporting date in } \\
\text { accordance with established costs procedure. }\end{array}$} & $\begin{array}{l}\text { Two ways of the subsequent evaluation of the } \\
\text { R\&D object: }\end{array}$ \\
\hline & $\begin{array}{l}\text { 1) Evaluation at the primary cost less } \\
\text { accumulated depreciation and accumulated } \\
\text { impairment losses; }\end{array}$ \\
\hline & $\begin{array}{l}\text { 2) Evaluation at the revalued amount less } \\
\text { accumulated depreciation and accumulated } \\
\text { impairment losses. }\end{array}$ \\
\hline
\end{tabular}

\subsection{List of Costs on the Innovation Project}

The study established the feasibility of inclusion of the costs of new technologies development or improvement of technologies already used in the costs of the innovation project.

List of costs of the innovation project:

1) Fixed assets depreciation (except for buildings and structures) and intangible assets used to perform the works (these assets are to be used only for the purposes of the innovation project);

2) Payment for the labor of employees involved in the innovation project implementation, according to Clauses 1 , 3, 16, 21 of Article 255 of the Tax Code of the Russian Federation. Clause 3 of Article 262 of the Tax Code of the Russian Federation contains another requirement: if during the innovation project implementation these employees get involved in the implementation of other activities of the taxpayer, the costs of the innovation project are considered corresponding amounts of labor costs paid to these employees in proportion to the time during which they have been involved for these works (www.nanonewsnet.ru);

3) The costs of the taxpayer for the purchase of raw materials and (or) the materials used in the production of goods, as well as on product packaging and other production and economic needs, for the purchase of tools, fixtures and other property that is not depreciable, and the acquisition (production) of fuel, water, energy of all kinds spent on technological purposes;

4) Other costs directly associated with the innovation project implementation, no more than $75 \%$ of the labor costs specified in Clause 2. It is important to note that a significant portion of these costs shall include mandatory deductions from the wages of employees involved in the innovation project implementation, into the pension fund, the Fund of compulsory health insurance, etc.;

5) The cost of innovation projects implemented by third parties.

Currently, companies should focus on the emergence and increase in transaction costs that may arise during the interaction of both internal and external customers, there can be occurred the number of internal conflicts between departments, the costs associated with inappropriate behavior of employees as in corporate structures it is significantly more difficult to monitor their activities and, as a consequence, control this type of costs.

With due regard to the level of errors at the evaluation of the cost of the innovation project at the stages of its life cycle, indicated in the table, at the evaluation of the cost of the innovation project the study proposes to take into account the costs incurred at each of the project stages. But each of the life cycle stages of the innovation project can be represented as an algorithm of sequential actions associated with each other, and to assess the cost, i.e. the costs for each of these blocks. This approach to the determination of the cost of the innovation project shall help to minimize the error in the calculation at the stages, traditionally defined to assess the project cost, that will determine an increase in investment attractiveness for foreign investors due to the higher degree of certainty in the innovation implementation and provide an opportunity to more accurately plan the budget of the enterprise in a whole to achieve the strategy and implementation of the targets.

\subsection{Methodology for Formation of the Cost of the Innovation Project}

The methodology for formation of the cost of the innovation project developed in the study is based both on the decomposition of stages of the innovation project into phases, and phases - into separate processes, and the value 
of the output parameters of each process in the "quality - time - cost" system, taking into account the direction of each life cycle stage of the innovation project, as well as on the method of additive convolution to calculate the integral index, reflecting the amount of the cost of the innovation project as a whole.

It is known that the activity of any enterprise, regardless of its ownership form, the type of activity, the industry and the size, it is necessary to begin with the development of basic provisions, which include the mission, vision and strategy, which are the aspects of strategic management level, and then it is necessary to turn to the operational level, which consists of a scheme of business processes, the definition of the relationships between these processes, the purpose of the indicators for each process output, which will be the basis of the methodology for formation of the budget of the innovation project (Kandrashina, 2004).

The first step in developing the methodology for formation of the cost of the innovation project shall be the decomposition of each stage of the life cycle to the level phases with the submission of the phases in the form of a scheme of interrelated processes of the organization (Figure 3).

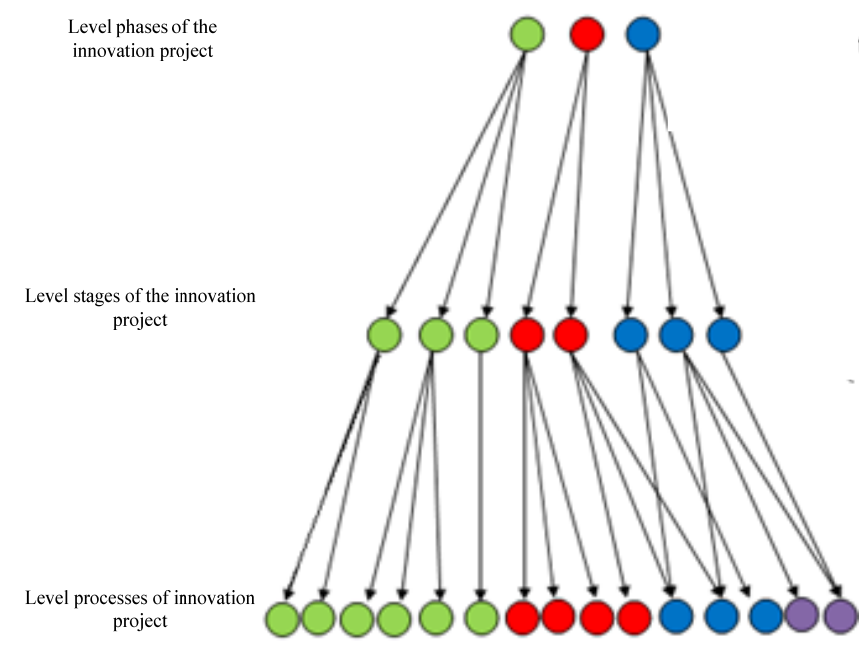

Figure 3. Level phases of the innovation project

The next step shall be the selection and description of the processes. The process approach is necessary for ensuring the strategic direction of the activity, also occurred the possibility of graphic representation and/or interpretation of the activity: the definition of areas of responsibility, that allows to specify requirements for personnel involved in the activities on development of more precise personnel arrangements, the definition of control points and critical points in the process of decomposition into sub-processes. Also, due to optimization of the organizational structure the process approach allows to accelerate the exchange of information and document control between different structural units (Smirnov, 2009, pp. 138-140; Earl, 1976, pp. 133-140).

The ISO standard of the series No. 9000 contains requirements for the implementation of the process-oriented model (Earl, 1976, pp. 133-140; Kodama, 1995):

- Allocation of processes to be determining the implementation of the project in the organization;

- Determination of the input data and output results of each process to determine the sequence and the interaction between these processes;

- Planning and providing the resources necessary for the functioning of processes and their management;

- Establishment of the extent of documentation and documentation of the business processes;

- Planning processes;

- The presence of the criteria and methods of evaluation of the functioning and organization of processes;

- Monitoring, evaluation and analysis of the processes;

- Development of corrective and preventive measures under the results of process monitoring. 
The process approach is associated with the other principles of company management, defined in the standard. At the same time it acts as a guiding principle, the observance of which inevitably entails the implementation of the other principles.

Thus, we have identified the necessity for construction of the process model in the enterprise, which will be the decomposition of the lifecycle stages of the innovation project.

\subsubsection{Sequence of Implementation Techniques}

The first phase in the decomposition of the processes within each stage of the innovation project is the establishment of the boundaries of the processes that specifies the area of activity, which requires the identification and consideration in the specific processes with the purpose of improvement of their effectiveness, including through the minimization of the functioning cost ratio.

The second phase is the appointment of the owners of each process, as a rule, choosing from the members of management personnel, as they have the power to organize the activities within the framework of the processes and all the follow-up activity will be carried out under the supervision of the mentioned persons.

The third phase involves the description of the activities implemented within the framework of business processes in order to identify and fix the existing order of the process operation and its participants, that is necessary for determination of the cost-based process area and its elimination.

The study shows the decomposition of the preproduction phase in the form of a scheme of interrelated processes (Figure 4).

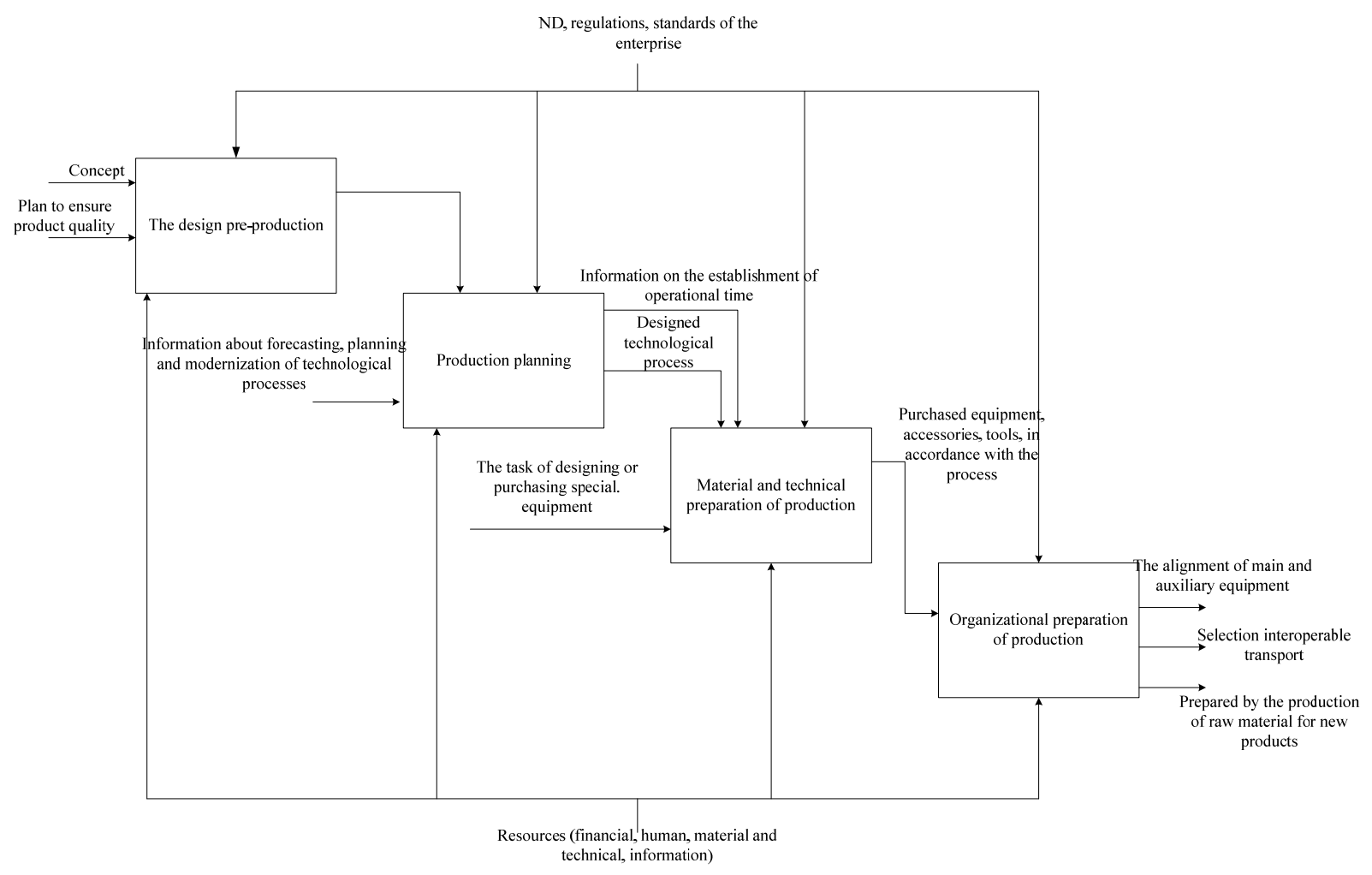

Figure 4. The decomposition of the preproduction phase

The next phase is to formulate indicators for process outputs based on the identification of requirements of internal consumers in the "quality - time - cost" system. It shall allow identifying and clarifying the requirements both on costs and agreement of the requirements of process consumers - both internal and external ones, - and it is necessary to take into account the specifics of each stage of the innovation project. Thus, in determining the cost of works performed within the framework of pre-design stage, special attention should be paid to the costs of intellectual activity. 
During the development stage occurs the increment of the organization's assets on fixed assets to inventories, which causes an increase in material costs.

A feature of the method for the determination of the indicators presented in the study is that the indicators are to be determined in the "quality - time - cost" system, which makes the process owners develop activities in their processes with regard to the focus on improving the quality of products, reducing the terms of its production and delivery, as well as reducing the cost of its production. In order to perform the procedures aimed at determination and registration of the process indicators we propose to use the data in Table 4.

Table 4. The data for implementation of the procedure for determination and registration of the process indicators

\begin{tabular}{|c|c|c|c|c|}
\hline $\begin{array}{l}\text { Process } \\
\text { inputs/ } \\
\text { outputs }\end{array}$ & $\begin{array}{l}\text { Requirements to process } \\
\text { inputs/outputs in the "quality } \\
\text { - time - cost" system }\end{array}$ & $\begin{array}{l}\text { Risk of failure to } \\
\text { comply } \\
\text { requirements }\end{array}$ & $\begin{array}{l}\text { Ranking } \\
\text { requirement } \\
\text { importance }\end{array}$ & $\begin{array}{l}\text { Process } \\
\text { performance } \\
\text { criterion }\end{array}$ \\
\hline
\end{tabular}

The first column of this table contains the outputs of a particular process, which is a component of the lifecycle stage of the innovation project, it is also determined the input of which process serves this output.

The second column specifies requirements for the output of the process under consideration in the "quality - time - cost" system. The feature of filling in this stage of the table is that the requirements for products, which is the output of the process, are set by its customer, in this case it is the owner of the following process, for which this product (design and technological documentation, information on the market state or change in customer requirements, semi-finished product or raw materials) is the process output. It is the owner of the process-customer who shall define the requirements for products supplied (i.e. to the process input), with respect to indicators of the products quality, delivery time and the amount of costs, as it is the sum of all costs incurred within each process, that shall be the total cost of the life cycle stages of the innovation project.

Due to the fact that one of the characteristics of the innovation project implementation is the uncertainty (i.e. a high degree of risk emergence), the third column notes the level of risk of failure to comply with the requirements that have been identified by the owner of the process-customer.

The next column sets the ranking of importance of requirements to the process outputs. The ranking is calculated together with the owner of the process-customer on three-point scale: low importance, significant requirement and high importance of customer requirements. This is caused by the uncertainty in the innovation project implementation, by limited funding and the necessity for implementation of the priorities of the innovation project, taking into account its orientation.

The last column introduces the process performance criterion, which reflects the basic requirements of the process consumers in accordance with their importance and the risk of failure to comply with these requirements.

Subsequently it is appropriate to define measurable or evaluable criteria for establishing the extent to which process customers' requirements are carried out. One of the features of this approach is the integration of indicators for the process performance with indicators determining the level of costs of the process performance, as noted in the table, together with the customers of this process that provides the combination of the function on optimization of the process-oriented model and cost management.

The fifth phase involves the necessity for evaluation of the variability of indicators which determine the efficiency of the process for determining the stability of the processes and identifying the reasons because of which the customer requirements cannot be complied. Based on the analysis of variability of processes developed corrective measures.

Thus, the described phases of the allocation of the enterprise processes can be represented as in Table 5 .

In evaluating the effectiveness of processes the trend of increasing the share of organizational and administrative costs shall be taken into account at all stages of the life cycle of the innovation project. Taking into consideration the above, on the example of one of the manufactures the study demonstrates deployment of goals of the innovation project up to the process level in order to identify performance indicators that take into account the level of costs of the process performance (Figure 5). 


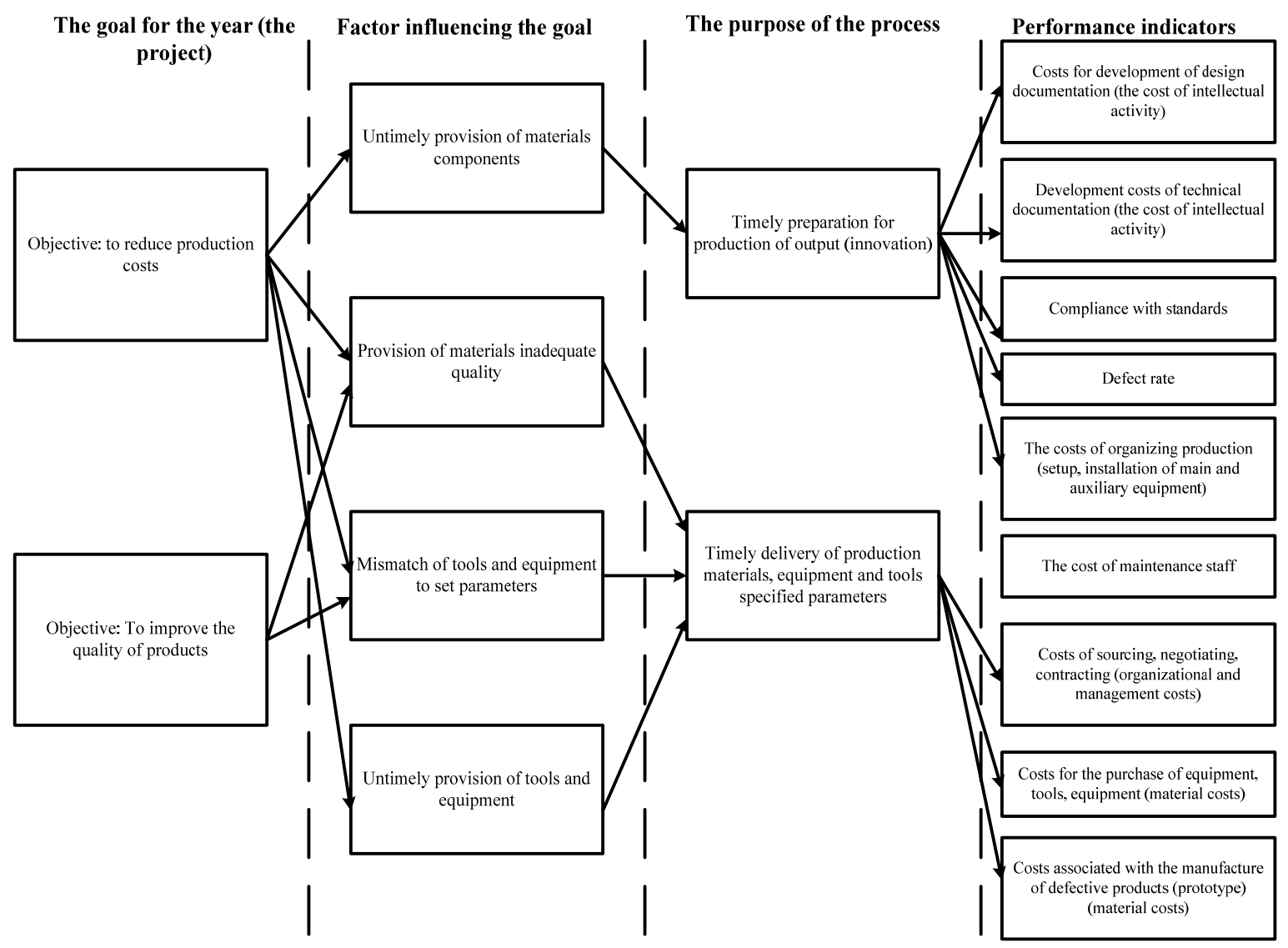

Figure 5. Deployment of the goal of the innovation project up to the level of processes

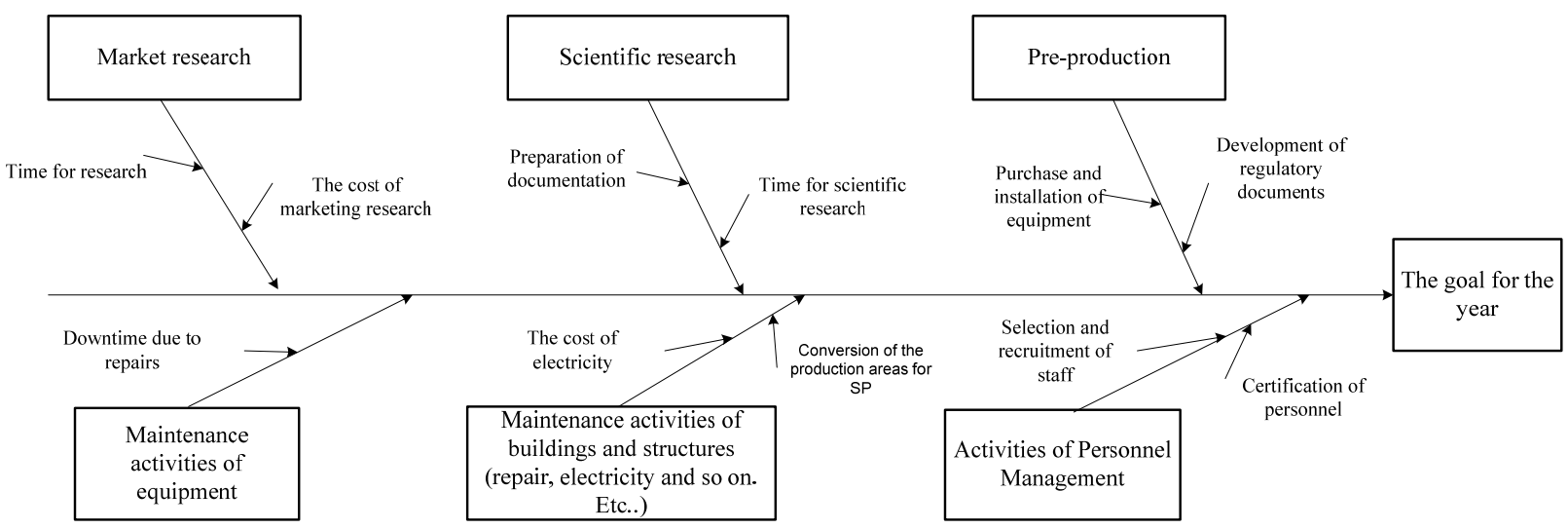

Figure 6. Determination of the factors affecting achievement of the goal

It is appropriate to consider the factors affecting the achievement of the goals for the subsequent development of corrective measures aimed at improving the efficiency and effectiveness of business processes (Figure 6).

Thus, the proposed method of evaluation of the cost of the innovation project for further budget formation and its adjustment is based on the representation of each of the life cycle stages of the innovation project as a scheme of interrelated processes. For the outputs of each process it is proposed to determine the performance indicators with the requirements of the owners of process-customers regarding the quality, time and cost of products or services rendered. In addition, the identification of factors affecting the process performance will allow to develop and apply corrective and preventive measures in order to improve process performance. 
Table 5. Phases of the allocation of the enterprise processes

\begin{tabular}{|c|c|c|}
\hline No. & Phase & Phase results \\
\hline 1 & $\begin{array}{l}\text { Description of the activities carried out within the } \\
\text { allocated processes "as they are" }\end{array}$ & $\begin{array}{l}\text { 1. Process maps containing the following: } \\
\text { - IDEF-models and SADT-diagrams of key and } \\
\text { supporting processes; }\end{array}$ \\
\hline 2 & $\begin{array}{l}\text { Determination of customer requirements to the output } \\
\text { process results }\end{array}$ & $\begin{array}{l}\text { - Customer requirements to the process output } \\
\text { data; }\end{array}$ \\
\hline 3 & $\begin{array}{l}\text { Definition of criteria for } \mathrm{e} \\
\text { performance efficiency, togeth }\end{array}$ & $\begin{array}{l}\text { - Measurable quantitative indicators of the } \\
\text { business processes performance; }\end{array}$ \\
\hline & & $\begin{array}{l}\text { - Qualitative criteria for evaluation of the } \\
\text { process performance; }\end{array}$ \\
\hline 4 & $\begin{array}{l}\text { Creating a system for collecting and analyzing process } \\
\text { performance data }\end{array}$ & - Indicators characterizing the level of costs. \\
\hline 5 & Evaluation of the process performance & is of \\
\hline 6 & $\begin{array}{l}\text { e process bot } \\
\text { ce }\end{array}$ & $\mathrm{y}$ \\
\hline 7 & $\begin{array}{l}\text { Analysis of the existing normative documentation } \\
\text { regulating the process activities }\end{array}$ & $\begin{array}{l}\text { 3. Monitoring data of the indicators of the } \\
\text { process performance including expenditure } \\
\text { indicators. }\end{array}$ \\
\hline 8 & Development of corrective measures & $\begin{array}{l}\text { 4. Plans for the development of corrective } \\
\text { measures aimed at improving the process } \\
\text { performance. }\end{array}$ \\
\hline
\end{tabular}

\section{Conclusion}

The cost of the innovation project shall consist of total costs of all life cycle stages of the innovation project, which, in turn, are estimated as the sum of costs of each phase separately calculated in the process performance evaluation, which is implemented by the algorithm described taking into account the characteristics of the innovation project, covering the uncertainty of the project implementation, incorporation of customer requirements and project orientation. The integral index of the cost of the innovation project (IP) is calculated as follows:

$$
\text { Costs of IP }=\sum_{i=1}^{n} \text { Costs at each stage } \in \sum_{i=1}^{n} \text { Costs at all phases } \in \sum_{i=1}^{n} \text { Costs within the processes }
$$

Consideration of factors affecting the processes performance shall allow to timely make amendments to the budget of the innovation project.

\section{Summary}

Thus, the developed methodology is aimed at increasing the reliability of the collected information on the cost of developing innovation projects, in addition, its application shall allow to rapidly amend the existing budgets of both the projects in particular and that of the organization as a whole.

Using this approach in practice provides the details of all life cycle stages of the innovation project up to the level of functions, followed by the application of the functional-cost analysis for determination of the cost of each stage. In turn, such a detailed decomposition of the project stages shall contribute to the optimal and correct development of network schedules of the project implementation.

It should also be mentioned the desirability of further research in this area, which is associated primarily with the identified shortcomings of this methodology, which lies in the fact that the application of the methodology for evaluation of the cost of the innovation project is possible for practical purposes only in organizations that have been certified for compliance with international standards in the field of quality management.

Another disadvantage is modest emergence of methodology associated with the difficulty of its application in the changes in the innovation project implementation.

Thus, there is an obvious necessity for further research in the area of determining the cost of innovation projects.

\section{References}

Atoyan, V., \& Plotnikov, A. (2009). Improving public financing innovation activities of enterprises in a crisis. 
Innovative society is a new historical era of civilizational development: Sb. Scientific (Vol. 2, Part 2). Saratov.

Brunner, F. (2011). Japanische Erfolgskonzepte: Kaizen, KVP, Lean Production Management, Total Productive Maintenance, Shopfloor Management, Toyota Production Management, GD': Lean Development. 2. Auflage. München: Carl Hanser Verlag.

Christensen, C., Burgelman, R., \& Wheelwright, C. (2008). Strategic Management of Technology and Innovation (5th ed.). USA: McGraw-Hill.

Cool, K., Costa, L., \& Dierickx, I. (2002). Constructing competitive advantage. In A. Pettigrew, H. Thomas, \& R. Whillington (Eds.), Handbook of strategy and management. London: SAGE.

Dodgson, M. (2009). The management of technological innovation: An international and strategic approach. England: Oxford University Press.

Dyer, J., Gregersen, H., Christense, C. (2011). The Innovator's DNA: Mastering the Five Skills of Disruptive Innovators. USA: Harvard Business Press.

Earl, S. (1976). Match Supply and Demand in Service Industries. Harvard Business Review, 11-12, 133-140.

Hill, Ch., \& Jones, R. (2009). Strategic Management (9t ${ }^{\mathrm{h}}$ ed.). Publishing House: Houghton Mifflin Company.

Horn, M., Johnson, C., \& Christensen, C. (2008). Disrupting Class: How Disruptive Innovation Will Change the Way the World Learns. USA: MCGRAW-HILL.

Kandrashina, E. (2004). Process-oriented management. Moscow: MELAP.

Kandrashina, E. (2009). Institutional conditions commercialization of innovations. Bulletin of the Samara State University of Economics, 5(55), 50-54.

Karpov, T. (2000). Accounting production as the initial stage of management accounting. Accounting, $20,56-57$.

Karpov, T. (2003). Management Accounting. Moscow: Audit: UNIP.

Kodama, F., \& Branscomb, M. (1995). Emerging Patterns of Innovation Sources of Japan's Technological Eadge. USA: Harvard Business School.

Korolev, O., Shamgunov, R. (2010). On the criteria and indicators of innovative development of the Russian economy. Initiative of the XXI century, 4, 63-67.

Laskowski, E. (2007). Innovative development as the basis for increasing the economic sustainability of production of the enterprises. Investment Management, 2, 19-31.

Laskowski, E., Narrow, J., \& Dovbakh, I. (2009). Formation of innovation economy in Russia. Chelyabinsk: SUSU.

Novikov, D. (2007). Project management: Institutional arrangements. Moscow: PMSOFT.

Smirnov, V. (2009). Problems of formation of the state innovation policy at the present stage. RISK: Resources, information, supply, competition, 2, 138-140.

Tukkel, I., Surin, A., \& Kultin, N. (2011). Innovative project management: The textbook. St. Petersburg: BHV-Petersburg.

Website about nanotechnology number 1 in Russia. (n. d.). Retrieved October 25, 2014, from http://www.nanonewsnet.ru

Wheelen, T., \& Hunger, J. (2009). Concepts in Strategic Management and Business Policy (12th ed.). New Jersey: Prentice Hall.

Wheelen, T., \& Hunger, J. (2011). Strategic Management and Business Policy: Toward Global Sustainability (12th ed.). New Jersey: Prentice Hall.

\section{Copyrights}

Copyright for this article is retained by the author(s), with first publication rights granted to the journal.

This is an open-access article distributed under the terms and conditions of the Creative Commons Attribution license (http://creativecommons.org/licenses/by/3.0/). 